\title{
Another Slow Recovery from Economic Disaster
}

The lesson learned from the Great Recession was that the initial stimulus was far too small. The subsequent austerity during the recovery directly obstructed a return to full employment. There had been hopes that a Biden administration would quickly implement an aggressive stimulus. In addition to measures to control the pandemic, the hoped-for stimulus would also include a large clean energy component and major expenditures on childcare and health care.

Given the outcome of the elections, there seems little hope for the amount of stimulus the economy needs. The Republicans are likely to maintain control of the Senate, although two January run-offs still provide some hope for the Democrats. This means that Majority Leader Mitch McConnell, the same person who openly worked to thwart the Obama presidency, would be in control for at least the first two years of the Biden presidency. If Biden wants to get back quickly to something like full employment and make progress on an agenda to limit global warming and reduce inequality, he will have to find creative paths that work around the obstructions of Mitch McConnell. This will be difficult, but not impossible.

One way that Biden may reduce unemployment is through the promotion of worksharing. Many European countries used worksharing in both the last and current recession to keep the unemployment rate relatively low, even as growth faltered. Germany was the champion in this area, managing to actually lower its unemployment rate in 2009 and 2010, even as its GDP loss was greater than in the US. Worksharing has won support across the political spectrum in the United States. John Boehner, who was the Republican Speaker of the House in 2011, supported measures to promote worksharing and many of the leading Republican economists have publicly endorsed proposals for increasing the use of worksharing, which is already part of the unemployment insurance system in most states.

One advantage worksharing has over other ways to lower unemployment is that it does not require substantial expenditures. It essentially means that the money used to pay unemployment benefits instead supplements the pay of workers who are putting in reduced hours. There is no principle that says it is better to pay a worker to be completely unemployed - with unemployment benefits - than to be partially unemployed with a worksharing supplement.

In the absence of large-scale stimulus, worksharing can also help to address other important problems. The pandemic is likely to permanently reshape the structure of our cities, as many more people work remotely. This will mean fewer people commuting to work each day. This is a great development from the standpoint of reducing the resources wasted in commuting, and even more so from the standpoint of lowering greenhouse gas emissions. Still, it means that many of the jobs associated with servicing this commuting population will disappear. Millions of people formerly employed in restaurants that provided lunch or dinner to people commuting, and workers in barber shops, hair salons, gyms, and dry-cleaning services located in downtown business districts, will not see their jobs return even when the pandemic is under control. Worksharing can maximize employment in these sectors, even as the total demand may be far less than before the pandemic. Worksharing may also help to change norms about work in the United States. The average work year in the US has 20 to $25 \%$ more hours than in countries like Germany, France and Denmark. Worksharing can be a step toward getting our work habits more

(C) The Author(s) 2020. Open Access: This article is distributed under the terms of the Creative Commons Attribution 4.0 International License (https://creativecommons.org/licenses/by/4.0/).

Open Access funding provided by ZBW - Leibniz Information Centre for Economics.
Dean Baker, Center for Economic and Policy Research, Washington DC, USA. 
in line with these countries, allowing people more time to spend with their families or in leisure activities.

In the absence of a large stimulus package, aggressive action by the Federal Reserve Board to promote growth will be useful. The current chair, Jerome Powell, has indicated that he fully intends to keep interest rates near zero until the economy is back to something close to full employment. This is not a substitute for fiscal stimulus, but it will be a boost to the economy.

Reducing student loan debt is another mechanism through which President Biden can unilaterally provide a boost to the economy. He can eliminate a substantial sum for all debtors and then move aggressively through the courts to eliminate debt accrued from corrupt for-profit colleges.

Ideally, we would have large subsidies for clean energy, conservation, and electric cars, but that will be difficult to do with a Republican-controlled Senate. However, it may be possible to get some support in these areas as these industries are now large employers, and Biden may be able to leverage that fact by slipping in funding in necessary appropriations bills. This will mean money for companies in Republican states and congressional districts. There are also administrative steps that can be taken, such as limiting the use of coal in power plants and requiring stronger controls on methane emissions from fracking operations. These can help slow global warming, even if the scale is nowhere near as large as required.

With regards to health care, if the Supreme Court does not completely strike down the Affordable Care Act, the Biden administration's main goal will be to make the insurance it provides more affordable. The direct path is through larger subsidies, but this would require action by Congress. If that path is blocked, Biden can lower costs, first and foremost by extensive use of Section 1498 of the Commercial Code. This provision allows the government to override patents, although it requires some compensation to patent holders. There are enormous potential savings from bringing the price of drugs closer to the free market price. In the case of prescription drugs, the savings could be as much as $\$ 400$ billion a year, or $1.8 \%$ of GDP. Savings on medical equipment could be close to one-third of this amount. It is not plausible that savings from Section 1498 could be anywhere near this large, but even $20 \%$ of these sums would go far toward making health care more affordable.

Inequality has been rising in the United States for 40 years as a result of deliberate policy. Its reversal is a major project, but one step that could go far would be to alter the dynamics of corporate governance. As it stands now, top management is largely able to run companies in their own interest. This is because the corporate boards, who ostensibly represent shareholders, owe their primary allegiance to top management. This is what allows CEOs to have salaries in the tens of millions of dollars, which bear little relationship to the returns they provide shareholders. A simple way to change this relationship would be to alter the triannual "Say on Pay" votes that go out to shareholders. These referendums, which became law as part of the 2010 Dodd-Frank financial reform act, give shareholders the opportunity to vote on the CEO's compensation package. Under the law, there is no consequence for a no vote, except perhaps some embarrassment for the corporate board. However, if the corporate boards were to lose their own pay if a Say on Pay vote was turned down, it would give them a serious incentive to think about paying CEOs less. And if we got our CEO's pay in line with where they were 40 to 50 years ago (\$2 to \$3 million, rather than $\$ 20$ million), it would have a huge impact on pay structures throughout the economy. It may be difficult to get a Republican Senate to approve this change, but it will be hard for them to call a proposal 'socialist,' when it gives shareholders more control over the companies they own.

If the Democrats could reach a period of unified control, they could push a far more aggressive agenda to meet the needs of the country and world. But given the outcome of the elections, they will have to be less ambitious and more creative. 